\title{
Analisis Usahatani Brokoli Organik (Brassica oleracea L.var. botrytis L.) Di Kelompok Tani Bangkit Merbabu Desa Batur Kecamatan Getasan Kabupaten Semarang
}

\section{(Analysis Of Farming System Organic In Broccoli (Brassica oleracea L.var. botrytis L.) In The Bangkit Merbabu Group Of Farmer Of Batur Village Of Getasan District Of Semarang Regency)}

\author{
Ahmat Yusub*, R. Pramono**, Harum Sitepu** \\ * Alumni Program Studi S-1 Agribisnis STIP Farming Semarang \\ ** Staf Pengajar Sekolah Tinggi Ilmu Pertanian Farming Semarang \\ ahmatyusub_c@yahoo.com
}

\begin{abstract}
ABSTRAK
Penelitian ini bertujuan untuk mengetahui seberapa besar pendapatan usahatani brokoli organik, kelayakan usahatani brokoli organik, mengetahui pengaruh biaya sarana produksi dan tenaga kerja terhadap pendapatan usahatani brokoli organik. Penelitian dilaksanakan pada bulan Juli sampai dengan September 2017. Metode Penelitian dilakukan berdasarkan deskriptif analisis dan ex post facto, penentuan sampel menggunakan metode sensus dengan 20 responden, pengumpulan data mengunakan data primer dan data sekunder. Metode analisis data yang digunakan adalah : pendapatan usahatani dan kelayakan usahatani dengan (RCR, BEP, dan ROI) menggunakan analisis matematis. Untuk mengetahui pengaruh biaya sarana produksi dan tenaga kerja menggunakan model regresi linier berganda (uji $F$ dan uji t) Hasil penelitian menunjukkan pendapatan usahatani brokoli organik sebesar Rp. 51.467.650,00/ha/musim, dengan nilai RCR $(2,02)$, , BEP ${ }_{(Q)} 4.026,25 \mathrm{~kg}$ (riil 8.143,67 kg), BEP $6.185,76$ (riil Rp. 12.500), dan nilai ROI (102,24\%). Maka usahatani di kelompok tani Bangkit Merbabu desa Batur kecamatan Getasan kabupaten Semarang menguntungkan dan layak diusahakan, ada pengaruh sangat nyata biaya pupuk, pestisida nabati dan mulsa terhadap pendapatan usahatani brokoli organik. Persamaan regresi linear diperoleh persamaan $Y=-181000000-8,563 X 1-1,751 X_{2}^{*}+2,935 X 3^{* \prime}-1,186 X 4^{\prime \prime}+5,716 X 5+8,726 X 6$ dimana $Y$ $=$ pendapatan, $X_{1}=$ benih, $X_{2}=$ pupuk, $X_{3}=$ pestisida nabarti, $X 4=$ mulsa, $X 5=$ wrapping dan $X 6=$ tenaga kerja. Kesimpulan : Usahatani brokoli organik di Kelompok tani Bangkit Merbabu desa Batur kecamatan Getasan kabupaten Semarang menguntungkan dan layak diusahakan, dan sarana produksi serta tenaga kerja sangat nyata berpengaruh terhadap pendapatan.
\end{abstract}

Kata kunci: Kelayakan; Usahatani; Brokoli Organik

\begin{abstract}
This research is to determine how many income, advisability farmed and determine the cost influence means of production and labour cost to net income of system organic broccoli. This research had been conducted in July until September 2017. The resaerch method applied is decriptive analysis and ex post facto, this methods collection survey of census with 20 respondents, and data collection with primary and secondary data. The analysis data method use is : for income and advisability farmed ( $R C R, B E P$, and $R O I)$ use mathematical analysis, to know the cost influence means of productions and labour cost by use a model Multiple Linear Regression ( $F$ test and $t$ test). The research showed that farmers organic broccoli income, that is $R p$. Rp. 51.467.650,00/acres/season, $R C R$ value (2.02), BEP (Q) $4.026,25 \mathrm{~kg}$ (real 8.143,67 kg), BEP ${ }_{(R p)} 6.185,76$ (real Rp.12.500), and ROI $(102,24 \%)$. Then effort in the Bangkit Merbabu group of farmer of Batur village of Getasan District of Semarang regency is advantageous, There is a very real effect the organic fertilizer, pesticide nabati and mulch to net income of organic broccoli farmers. And the results obtained from the linear regression analysis equation $Y=-181000000-8,563 X 1-1,751 X_{2}^{\prime \prime}+2,935 X 3^{* \prime}-1,186 X 4^{\prime \prime}+5,716 X 5+8,726 X 6$ that $Y=$ income, $X_{2}=$ seed, $X_{2}=$ organic fertilizer, $X_{3}=$ pesticide nabati, and $X_{4}=$ mulch, $X 5=$ Wrapping and $X 6=$ labour. The conclusion: The farmeing system of organic broccoli in the Bangkit Merbabu group of farmer of Batur village of Getasan district of Semarang regency is advantageous profitable and suitable. Means of production are very real effect on the system organic broccoli farm income .
\end{abstract}

Key words : Analysis, Farming, Broccoli Organic 


\section{PENDAHULUAN}

Pada akhir-akhir ini masyarakat dunia mulai sadar akan bahaya yang ditimbulkan oleh penggunaan bahanbahan kimia berbahaya dalam pertanian seperti pupuk dan pestisida kimia, hormon tumbuh dalam produksi pertanian sampai penggunaan mesin-mesin pertanian.

Dampak negatif yang ditimbulkan dari penggunaan bahan-bahan kimia tersebut tidak hanya dapat merugikan kesehatan tubuh konsumen yang mengkonsumsi hasil produksi pertanian itu, tetapi juga membahayakan kelangsungan daur hidup unsur-unsur hara dalam tanah, lingkungan serta ekosistem lain disekitarnya. Seiring dengan meningkatnya kesadaran masyarakat akan kesehatan, kini masyarakat pun mulai beralih kepada gaya hidup sehat dan alami atau "back to nature" yang mengutamakan pangan yang sehat dan bergizi tinggi tanpa kandungan bahan-bahan kimia.

Hal ini berdampak positif terhadap perkembangan pemasaran produkproduk organik yang kian pesat, baik di pasar domestik maupun internasional. Di pasar domestik terlihat dengan semakin banyaknya supermarket, outlet maupun gerai-gerai khusus yang menjual berbagai jenis produk pertanian organik. Masih banyak lagi kegiatan-kegiatan yang dilaksanakan oleh Lembaga Swadaya Masyarakat (LSM), kelompok tani, perseorangan dan perusahaan yang bergerak dalam bidang pertanian organik (Sutanto, 2002).

Produk pertanian organik Indonesia hampir semuanya adalah produk pertanian belum diolah (fresh product), salah satunya adalah sayuran organik yang sangat digemari oleh masyarakat. Brokoli organik merupakan salah satu jenis sayuran organic yang banyak dibudidayakan. Perkembangan produksi brokoli organik dari tahun ke tahun cenderung meningkat. Hal ini disebabkan adanya perbaikan teknologi atau teknik penanaman dalam usahatani brokoli organik. Salah satu daerah yang menghasilkan brokoli organik di Jawa Tengah adalah kecamatan Getasan kabupaten Semarang.

Kecamatan Getasan kabupaten Semarang merupakan salah satu sentra produksi sayuran organik khususnya brokoli organik di Jawa Tengah. Salah satu pelaku usaha atau petani yang masih konsisten berbudidaya brokoli organik di kecamatan Getasan kabupaten Semarang adalah Kelompok tani Bangkit Merbabu. Penanaman brokoli organik di kelompok tani Bangkit Merbabu desa Batur kecamatan Getasan kabupaten Semarang tersebut telah berlangsung sekitar 8 tahun.

Awalnya penanaman brokoli organik di kelompok tersebut dilakukan melalui sistem penanaman konvensional, kemudian pada tahun 2008 kelompok tani Bangkit Merbabu desa Batur kecamatan Getasan kabupaten Semarang mencoba suatu teknik penanaman organik yang dalam kegiatan budidayanya tidak menggunakan bahan-bahan kimia berbahaya seperti pupuk, pestisida dan lain-lain. Teknik penanaman organik ini diharapkan nantinya dapat menghasilkan produk brokoli organik yang jauh lebih aman untuk dikonsumsi dibandingkan produk brokoli organik hasil penanaman konvensional. Sejak tahun 2008 kegiatan usahatani di kelompok tani Bangkit Merbabu desa Batur kecamatan Getasan kabupaten Semarang sudah menerapkan budidaya organik salah satunya brokoli, bahkan kelompok tani Bangkit Merbabu desa Batur kecamatan Getasan kabupaten Semarang tersebut sudah mendapat sertifikasi organik Indonesia pada tahun 2012 oleh Lembaga Sertifikasi 
Organik INOFICE dan pada tahun 2016 mendapatkan sertifikasi organik internasional standard Eropa dan standard Jepang Oleh Lembaga Sertifikasi Control Union.

Kegiatan usahatani brokoli organik di kelompok tani Bangkit Merbabu desa Batur kecamatan Getasan kabupaten Semarang berjalan dengan baik. Dimana para petani optimis terhadap tingkat produksi brokoli organik yang akan mereka peroleh dari usahatani brokoli secara organik.

Usahatani brokoli organik diperlukan jumlah tenaga kerja yang banyak, mengingat budidaya organik membutuhkan tenaga kerja yang intensif didalam perawatan terutama dalam pengendalian hama yang mengandalkan pengendalian secara mekanik atau manual . Pangsa pasar untuk produk organik relatif masih sedikit, hal ini mengingat segmen pasar untuk produkproduk organik masih terbatas pada kalangan menengah keatas. Hal-hal tersebut diatas tentu saja menjadi penghambat bagi petani untuk mengembangkan usahatani Brokoli organik. Oleh karena itu, pada penelitian ini akan dilihat bagaimana penerapan usahatani brokoli organik yang dilakukan oleh para petani di Kelompok tani Bangkit Merbabu desa Batur kecamatan Getasan kabupaten Semarang dan selanjutnya akan dianalisis kelayakan usahatani Brokoli organik, sehingga pada akhirnya hasil analisis tersebut dapat menjadi acuan bagi para petani sekaligus meyakinkan para petani di kelompok tani Bangkit Merbabu desa Batur kecamatan Getasan kabupaten Semarang dalam membudidayakan brokoli secara organik.

\section{METODE PENELITIAN}

Penelitian ini dilaksanakan di desa Batur kecamatan Getasan kabupaten Semarang. Penelitian ini dilaksanakan selama 6 bulan dimulai dari bulan Maret September 2017. Penelitian dilakukan berdasarkan deskriptif analisis yang artinya menganalisis pendapatan yang sudah berlangsung atau berdasarkan kenyataan dan ex post facto yang artinya penelitian yang dilakukan untuk meneliti peristiwa yang telah terjadi yang kemudian merunut ke belakang untuk mengetahui faktor-faktor yang dapat menimbulkan kejadian tersebut. Adapun fokus penelitian adalah: "Analisis Usahatani Brokoli Organik".

Jumlah petani di kelompok tani Bangkit Merbabu desa Batur kecamatan Getasan kabupaten Semarang yang berjumlah 20 (dua puluh) responden. Teknik yang digunakan dengan sampling jenuh atau sensus, artinya seluruh populasi diteliti, karena jumlah populasi lebih keci dari 100 responde (Arikunto,S., 1998).

Data penelitian ini, di peroleh melalui Wawancara, Observasi, Dokumentasi.Metode wawancara yaitu metode pengumpulan data dengan jalan tanya jawab secara terstruktur yang diisi atau dikerjakan secara lisan ataupun tertulis menggunakan alat bantu berupa pertanyaan kuesioner. Dalam metode observasi ini peneliti terlibat secara langsung pada objek yang diteliti baik pengamatan atau perhitungan. Metode dokumentasi yaitu dengan cara mencatat hal yang berkaitan dengan penelitian yang diperoleh dari instansi terkait, misalnya dari Kelurahan dan Dinas merupakan data sekunder.

Untuk mengetahui pendapatan usahatani brokoli adalah dengan menggunakan rumus:

Pendapatan usaha tani adalah selisih antara penerimaan dan semua biaya produksi (Soekartawi, 1995). 
$\mathrm{Pd} \quad=\mathrm{TR}-\mathrm{TC}$

$\mathrm{Pd} \quad=$ Pendapatan

$\mathrm{TR}=$ Total penerimaan

TC = Total biaya

Analisis kelayakan meliputi:

R/C (RCR) adalah singkatan dari Revenue Cost Ratio, atau dikenal sebagai perbandingan (nisbah) antara penerimaan dan biaya.

Kriteria uji: jika $R / C>1$, layak untuk diusahakan; Jika R/C < 1, tidak layak untuk diusahakan (Soekartawi, 1995).

Dengan mengetahui titik BEP, analis dapat mengetahui pada volume penjualan, berapa perusahaan mencapai titik impasnya, yaitu tidak rugi, tetapi juga tidak untung sehingga apabila penjualan melebihi titik itu, maka perusahaan mulai mendapatkan untung.

$$
\begin{aligned}
& \text { BEP Produksi }=\frac{\text { Total Biava Produksi }}{\text { Harga Satuan Produksi }} \\
& \text { BEP Harga }=\frac{\text { Total Biava Produksi }}{\text { Total Produksi }}
\end{aligned}
$$

Return Of Investmen (ROI) digunakan untuk mengetahui total biaya produksi yang dikeluarkan dan kapan akan kembali, yaitu pendapatan yang diperoleh lebih besar dari biaya produksi yang dikeluarkan dalam satu periode usaha (Arikunto 2010).

$$
\mathrm{ROI}=\frac{\text { Keuntungan }}{\text { Modal Produksi }} \times 100 \%
$$

Analisis regresi linier berganda digunakan untuk mengetahui besarnya pengaruh penggunaan biaya faktor-faktor produksi terhadap pendapatan usahatani. Regresi linier berganda adalah metode statistik yang digunakan untuk membentuk model hubungan (regresi) antara variabel terikat (Y) dengan lebih dari satu variabel yang bebas (X) (Gujarati, 1997), persamaan yang digunakan adalah:

$$
\begin{aligned}
& Y_{1}=a+b_{1} X_{1}+b_{2} X_{2}+\ldots . . b_{n} X_{n} \\
& \text { Keterangan: } \\
& \mathrm{Y}=\text { Pendapatan } \\
& \text { a } \quad=\text { Konstanta } \\
& b_{n} \ldots b_{n}=\text { Koefisien Regresi } \\
& \mathrm{X}_{1}=\text { Sarana Produksi ke-1 } \\
& \mathrm{X}_{2}=\text { Sarana Produksi ke-2 } \\
& \mathrm{Xn}=\text { Sarana Produksi ke-n }
\end{aligned}
$$

Analisis of variance (ANOVA) $\mathrm{F}$ dgunakan untuk mengetahui apakah faktor indenpenden (X) secara simultan/serempak berpengaruh signifikan terhadap variabel dependent (Y). Uji t digunakan untuk menguji sebuah variabel indenpenden $X$ benar-benar memberikan kontribusi terhadap variabel terkait dependen Y. Analisis koefisien determinasi untuk mengetahui besarnya kontribusi variabel $X$ (indenpenden variabel) adalah variabel faktor produksi terhadap nilai variabel $Y$ (idependen variabel) adalah variabel pendapatan usahatani brokoli organik, maka digunakan koefisien determinasi $\left(R^{2}\right)$.

\section{HASIL DAN PEMBAHASAN}

\section{A. Analisis Pendapatan Usahatani Brokoli Organik}

Biaya tetap tediri dari biaya sewa lahan, sedangkan biaya variabel terdiri dari biaya benih, biaya pupuk, biaya pestisiada nabati, biaya mulsa, biaya wrapping, dan biaya tenaga kerja. Penerimaan merupakan hasil perkalian antara total produksi $(\mathrm{kg})$ dengan harga jual tiap satuanberat, (Rp). Pendapatan merupakan hasil bersih dari kegiatan suatu usahatani yang diperoleh dari hasil bruto (kotor) dikurangi biaya yang digunakan dalam proses produksi dan biaya pemasaran. Rekapitulasi data Produksi, Penerimaan dan Pendapatan disajikan pada Tabel 1. 
Tabel 1. Rata-rata Biaya Produksi, Penerimaan dan Pendapatan Tiap Hektar Usahatani Brokoli organik per Satu Musim Tanam

\begin{tabular}{clr}
\hline No. & \multicolumn{1}{c}{ Uraian } & Usahatani Brokoli organik \\
\hline 1 & Biaya Produksi (Rp) & \\
a. Biaya Tetap & $4.000 .000,00$ \\
& 1). Sewa Lahan (Rp) & $4.000 .000,00$ \\
& Total Biaya Tetap (RP) & \\
b. Biaya Variabel & $2.531 .250,00$ \\
1). Benih (Rp) & $7.198 .333,33$ \\
2). Pupuk (Rp) & $1.053 .333,33$ \\
3). Pestisida Nabati (Rp) & $2.715 .000,00$ \\
4). Mulsa (RP) & $6.514 .933,33$ \\
5). Wrapping (Rp) & $26.315 .333,33$ \\
6). Tenaga Kcrja (Rp) & $46.328 .183,33$ \\
Total Biaya Variabel & $50.328 .183,33$ \\
Total Biaya Produksi (Rp) & $8.143,67$ \\
Penerimaan (Rp) & $12.500,00$ \\
a. Produksi (Kg) & $101.795 .833,33$ \\
b. Harga jual (Rp/Kg) & $51.467 .650,00$ \\
\hline
\end{tabular}

Sumber data: Data Primer diolah Tahun 2017.

Pada Tabel 1. diatas, maka diperoleh rata-rata total biaya produksi tiap hektar usahatani brokoli organik di kelompok tani Bangkit Merbabu desa Batur kecamatan Getasan kabupaten Semarang adalah sebesar Rp. 50.328.183,33 biaya tersebut lebih rendah dibanding dengan penelitian sebelumnya oleh Susilawati (2012) mengenai analisis keberlanjutan usahatani sayuran organik dalam aspek ekonomi bahwa usaha brokoli organik membutuhkan biaya total sebesar Rp. 101.529.320,-. $\quad$ Hal tersebut terjadi karena lokasi penelitian sebelumnya di tingkat perausahaan sedangkan lokasi peneliti berada pada tingkat petani langsung.

Biaya biaya yang dikeluarkan ditingkat perusahaan lebih besar seperti sewa lahan, tenaga kerja dan sarana produksi dibanding di tingkat petani. Upah tenaga kerja di perusahaan berdasarkan upah minimum regional (UMR) sedangkan ditingkat petani upah berdasarkan kesepakatan sosial di wilayah tersebut dengan mempertimbangkan kemampuannya sehinnga biaya lebih rendah di tingkat petani. Untuk pengadaan sarana produksi ditingkat perusahaan diperoleh dari perusahaan lain sehingga biaya tinggi sementara sarana produksi di petani khususnya pupuk dan pestisida nabati dibuat mandiri oleh kelompok tani sendiri.

Berdasarkan Tabel 1. dapat diketahui bahwa total biaya produksi usahatani brokoli organik di kelompok tani. Bangkit Merbabu sebesar Rp. 50.328.183,33 dan penerimaan sebesar Rp. 101.795.833,33. Analisis rata-rata pendapatan usahatani di kelompok tani Bangkit Merbabu diperoleh dari penerimaan dikurangi total biaya produksi. Dari analisis rata-rata pendapatan per hektar/tanam usahatani brokoli organik di kelompok tani Bangkit Merbabu diperoleh sebesar Rp. $51.467 .650,00$. Pendapatan usahatani brokoli organik di kelompok tani Bangkit Merbabu tersebut lebih rendah dibanding dengan penelitian sebelumnya oleh Susilawati (2012) mengenai analisis keberlanjutan usahatani sayuran organik dalam aspek ekonomi bahwa usaha brokoli organik memperoleh pendapatan sebesar Rp. 
73.045.780,00. Hal tersebut dipengaruhi oleh jumlah produksi dan harga brokoli organik. Jumlah produksi pada penelitian sebelumnya $10.000 \mathrm{~kg} / \mathrm{ha}$ sementara di kelompok tani Bangkit Merbabu 8.143,67 kg/ha. Tingginya hasil produksi pada lokasi penelitian sebelumnya dikarenakan menggunakan tenaga kerja yang profesional sedangkan di kelompok tani Bangkit Merbabu tenaga kerja masih terbatas oleh petani itu sendiri dengan ketrampilan dan pengetahuan yang masih terbatas serta variatif.

Mengingat budidaya organik membutuhkan penanganan tenaga kerja yang lebih intensif sehingga hasil produksi lebih maksimal. Untuk harga brokoli pada usahatani brokoli organik di kelompok tani Bangkit Merbabu adalah
Rp. $12.500,00$ atau lebih rendah dibanding dengan penelitian sebelumnya yaitu Rp. 17.400.000, Proses penjualan brokoli organik kelompok tani Bangkit Merbabu sampai pasar masih melalui perantara sementara proses penjualan pada penelitian sebelumnya bisa secara langsung sampai pasar. Sehingga rantai pemasaran pada kelompok tani Bangkit Merbabu lebih panjang dan harga ditingkat petani lebih rendah.

\section{A. Analisis Kelayakan Usahatani}

RCR merupakan perbandingan (nisbah) antara penerimaan dan biaya atau perbandingan antara penerimaan dengan total biaya produksi. Hasil analisis RCR Usahatani Brokoli organik disajikan pada Tabel 2.

Tabel 2. HasilAnalisis RCR Usahatani Brokoli organik

\begin{tabular}{ccccc}
\hline No. & Uraian & Penerimaan (Rp) & Total Biaya Produksi (Rp) & RCR \\
\hline 1 & Brokoli organic & $101.795 .833,33$ & $50.328 .183,33$ & 2,02
\end{tabular}

Sumber: Data primer yang diolah tahun 2017

Berdasarkan Tabel 2. diperoleh nilai RCR usahatani brokoli organik adalah sebesar 2,02 atau $>1$, artinya setiap penggunaan input sebesar $R p$ 1,00 akan memberikan keuntungan sebesar Rp. 1,02. Nilai RCR pada usahatani brokoli organik di kelompok tani Bangkit Merbabu lebih besar dibanding dengan penelitian sebelumnya oleh Susilawati (2012) mengenai analisis keberlanjutan usahatani sayuran organik dalam aspek ekonomi bahwa usaha brokoli organik memperoleh nilai RCR 1,72.

Tingginya nilai RCR pada usahatani brokoli organik di kelompok tani Bangkit Merbabu dipengaruhi besarnya selisih antara penerimaan dan biaya produksi yaitu jumlah penerimaan lebih besar 2 kali lipat dari total biaya produksi. Hal tersebut dikarenakan biaya produksi seperti pupuk, pestisida nabati dan pembibitan bisa dibuat mandiri oleh kelompok tani begitu juga tenaga kerja berasal dari lingkungan sendiri. Sementara harga jual brokoli stabil dan cukup tinggi serta tidak terpengaruh oleh harga pasar karena kelompok tani menerapkan sistem pemasaran satu pintu. Selain itu brokoli organik memiliki kulaitas yang bagus yaitu bebas dari residu kimia sintetis.

Analisis BEP yang digunakan untuk menganalisis kelayakan usahatani dalam penelitian ini ada 2 macam, yaitu:

a. $\quad B P_{(Q)}$ produksi yaitu untuk menentukan kuantitas produksi minimal yang harus dicapai.

b. $\quad B P_{(R p)}$ harga yaitu untuk menentukan harga minimal produk tiap satuan rupiah agar usahatani tidak mengalami kerugian atau usahatani dalam kondisi impas. 
Tabel 3. Hasil Analisis BEP Usahatani Brokoli organic

\begin{tabular}{llr}
\hline No. & \multicolumn{1}{c}{ Uraian } & Usahatani Brokoli organik \\
\hline 1 & Total Biaya Produksi (Rp) & $50.328 .183,33$ \\
2 & Hasil Produksi $(\mathrm{Kg})$ & $8.143,67$ \\
3 & Harga satuan(Rp/kg) & $12.500,00$ \\
4 & BEP Q $(\mathrm{kg})$ & $4.026,25$ \\
& Riil & $8.143,67$ \\
5 & BEP harga (Rp) & $6.185,76$ \\
& Riil & $12.500,00$
\end{tabular}

Sumber : Data Primer diolah Tahun 2017

Berdasarkan Tabel 3. dapat diketahui nilai - nilai BEP sebagai berikut :

Nilai $\mathrm{BEP}_{(\mathrm{Q})}$ Produk adalah sebesar $4.026,2 \mathrm{~kg}$ per ha yang berarti bahwa jumlah hasil produksi minimum yang harus diperoleh agar usahatani impas. Jika hasil produksi di atas (lebih besar) daripada $\mathrm{BEP}_{(\mathrm{Q})}$ maka usahatani brokoli organik menguntungkan dan layak untuk diusahakan. Dari hasil penelitian diketahui bahwa rata-rata basil produksi dalam satu kali masa panen tiap hektar usahatani brokoli organik adalah sebesar $8.143,67 \mathrm{~kg}$. Artinya bahwa produksi rata-rata brokoli organik adalah lebih besar dari pada nilai $\mathrm{BEP}_{(\mathrm{Q})} \quad 4.026,2 \mathrm{~kg}$. Besarnya hasil produksi pada usahatani brokoli organik di kelompok tani Bangkit Merbabu karena budidaya yang dilakukan dengan menerapkan sistem pertanian organik. Dimana dengan sistem pertanian organik mampu menjaga struktur dan kesuburan tanah bahkan daya tahan serangan dari hama penyakit juga cukup bagus. Sehinnga tanaman borokoli tumbuh lebih sehat dan hasil produksi meningkat atau tinggi.

Nilai $\quad \mathrm{BEP}_{(\mathrm{Rp})}$ harga rata-rata sebesar Rp. 6.185,76 per $\mathrm{kg}$ yang berarti bahwa harga terendah di tingkat petani brokoli organik yang harus dicapai agar usahatani dapat impas. Jika harga brokoli organik per kg di pasaran di atas harga $\mathrm{BEP}_{(\mathrm{Rp})}$ harga, maka usahatani brokoli organik menguntungkan dan layak untuk diusahakan. Dari hasil penelitian diketahui bahwa rata-rata harga brokoli organik tiap satuan $\mathrm{kg}$ di tingkat petani adalah sebesar Rp $12.500,00$. Nilai $\mathrm{BEP}_{(\mathrm{Rp})}$ harga pada usahatani brokoli organik di kelompok tani Bangkit Merbabu g lebih rendah dibanding dengan penelitian sebelumnya oleh Susilawati (2012) mengenai analisis keberlanjutan usahatani sayuran organik dalam aspek ekonomi bahwa usaha brokoli organik memperoleh Rp. 10.095,00. BEP $(R p)$ harga.

Rendahnya Nilai $\mathrm{BEP}_{(\mathrm{Rp})}$ harga pada usahatani brokoli organik di kelompok tani Bangkit Merbabu dibandingkan dengan penelitian sebelumnya oleh Susilawati (2012), karena biaya produksi pada usahatani brokoli organik di kelompok tani Bangkit Merbabu lebih murah. Hal tersebut dikarenakan penelitian sebelumnya dilakukan ditingkan perusaahan sedangkan lokasi peneliti berada pada tingkat petani langsung. Dimana Biaya biaya yang dikeluarkan ditingkat petani lebih murah seperti sewa lahan, tenaga kerja dan sarana produksi dibanding di tingkat perusahaan.

Return Of Investmen digunakan untuk mengetahui total biaya produksi yang dikeluarkan dan kapan akan kembali, yaitu pendapatan yang diperoleh lebih besar dari biaya produksi yang dikeluarkan dalam satu periode usaha. Pada Tahel 10 berikut diuraikan hasil analisis ROI usahatani brokoli organik di kelompok tani Bangkit Merbabu. 
Tabel 4. Hasil Analisis ROI Usahatani Brokoli organic Organik per Hektar/Periode Tanam di Kelompok tani Bangkit Merbabu desa Batur kecamatan Getasan kabupaten Semarang.

\begin{tabular}{ccccc}
\hline No. & Uraian & Pendapatan (Rp) & Total Biaya Produksi (Rp) & ROI \\
\hline 1 & Brokoli organik & $51.467 .650,00$ & $50.328 .183,33$ & 102,24 \\
\hline
\end{tabular}

Sumber : Data primer yang diolah Tahun 2017

Hasil analisis usahatani brokoli organik di kelompok tani. Bangkit Merbabu diperoleh nilai ROI sebesar $102,24 \%$. Tingginya nilai ROI karena jumlah pendapatan lebih besar dari total biaya produksi. Dimana biaya produksi usahatani brokoli organik di kelompok tani. Bangkit Merbabu rendah karena dengan menerepkan sistem pertanian organik khususnya pupuk dan pestisida nabati bisa dibuat secara mandiri oleh kelompok tani sementara nilai ekonomis atau nilai jual brokoli organik cukup tinggi bahkan fluktuasi harga stabil. Hal ini menunjukkan bahwa usahatani brokoli organik di kelompok tani. Bangkit
Merbabu dapat menegmbalikan modal dalam satu kali musim tanam bahkan juga mendapatkan keuntungan sebesar 2,24\% dari modal yang telah diinvestasikan.

\section{A. Pengaruh Biaya Sarana Produksi Usahatani Brokoli Organik terhadap Pendapatan Petani}

Analisis data dilakukan dengan program SPSS sehingga dihasilkan olahan data dari usahatan tersebut. Berdasarkan lampiran 8, maka analisis datanya pada tabel 5 berikut.

Tabel 5. Hasil Analisis Regresi Linier Berganda Usahatani Brokoli Organik per Hektar/Periode Tanam di Kelompok tani Bangkit Merbabu desa Batur kecamatan Getasan kabupaten Semarang.

\begin{tabular}{clrr}
\hline No & Uraian & Nilai & Signifikan \\
\hline 1 & F Hitung & 109,394 &, $000^{\mathrm{a}}$ \\
2 & Konstanta a (intersep) & $-181010603,760$ & 0,145 \\
3 & Koefisien X (benih) & $-8,563$ & 0,152 \\
4 & Koefisien X2 (pupuk) & $-1,751$ & 0,029 \\
5 & Koefisien X3 (pestisida nabati) & 2,953 & 0,001 \\
6 & Koefisien X4 (mulsa) & $-1,186$ & 0,000 \\
7 & Koefisien X5 (wrapping) & 5,716 & 0,509 \\
8 & Koefisien X6 (tenaga kerja) & 8726 & 0,199 \\
9 & Determinasi (R2) & 0,981 &
\end{tabular}

Dari penyajian Tabel 5, maka diperoleh persamaan regresi linier berganda

$$
Y=-181010603,760-8,563 X_{1}-1,751 X_{2}^{*}+2,935 X_{3}^{* *}-1,186 X_{4}^{* *}+5,716 X_{5}+8,726 X_{6}
$$

Berdasarkan Lampiran 8, diperoleh nilai $F_{\text {hitung }}$ sebesar 109,394 dengan signifikan 0,000, dengan bersama-sama variabel sarana produksi yang terdiri dari benih, pupuk organik, pestisida nabati, mulsa, wraping dan tenaga kerja berpengaruh sangat nyata terhadap pendapatan. Secara umum usahatani brokoli organik sebagai berikut :

sarana produksi pada usahatani brokoli organik di kelompok tani Bangkit Merbabu dibuat secara mandiri oleh kelompok tani sehingga ada penghematan biaya seperti pupuk dan pestisida nabati serta tenaga kerja yang berasal dari lingkungan sendiri. Sehingga dengan biaya produksi yang lebih rendah dan harga yang cukup 
tinggi usahatani brokoli organik berpengaruh terhadap besarnya pendapatan.

Nilai koefisien regresi variabel benih $\left(X_{1}\right)$ sebesar - 8,563 yang artinya jika biaya benih ditambah satu satuan biaya, maka variabel pendapatan usahatani akan mengalami penurunan sebesar 8,563 unit (Rp) dengan asumsi pengunaan biaya pupuk, pestisida nabati, mulsa, wraping dan tenaga kerja tetap. Jarak tanam di lokasi penelitian mengunakan $40 \times 40 \mathrm{~cm}$. Menurut Rukmana (1994), jarak tanam budidaya brokoli organik yang sesuai adalah $70 \mathrm{x}$ $30 \mathrm{~cm}$, sehingga pengunaan bibit perlu dikurangi dengan cara memperlebar jarak tanam agar kebutuhan bibit berkurang dan pendapatan usahatani dapat meningkat.

Nilai koefisien regresi variabel pupuk $\left(\mathrm{X}_{2}\right)$ sebesar $-1,751$ yang artinya jika penambahan biaya pupuk satu satuan biaya maka pendapatan usahatani mengalalami penurunan sebesar 1,751 unit dengan asumsi pengunaan pengunaan biaya benih, pestisida nabati, mulsa, wraping dan tenaga kerja tetap. Menurut Rukmana (1994) Dosis pupuk kandang yang diberikan sebanyak 12.5 sampai 17.5 ton/ha dan diberikan satu minggu sebelum tanam. Pengunaan pupuk dilokasi penelitian mengunakan pupuk kandang kurang lebih 6 ton/ha dan pupuk cair organik 20 //ha sehingga perlu penambahan keragaman jenis pupuk biologis tanah, seperti bacteri trichoderma yang berfungsi sebagai agen hayati dan stimulator pertumbuhan tanaman dan penambahan dosis pupuk agar hasil produksi naik dan pendapatan usahatani meningkat. Penambahan dosis pupuk alternatifnya dengan penambahan dosis pupuk cair dimana hal tersebut akan lebih menghemat alokasi biaya penggunaan pupuk. Selain itu pupuk cair juga lebih mudah diserap tanaman dibanding dengan pupuk padat

Nilai koefisien regresi variabel Pestisida nabati $\left(X_{3}\right)$ sebesar 2,935 yang artinya jika penambahan biaya pestisida nabati satu satuan biaya maka pendapatan usahatani mengalami kenaikan sebesar 2,935 unit dengan asumsi pengunaan pengunaan biaya benih, pupuk, mulsa, wraping dan tenaga kerja tetap. Menurut Sudarminto (2015) Pengendalian OPT (organisme pengganggu tanaman) dilakukan tergantung pada OPT yang menyerang. Pengendalian dengan pestisida nabati dilakukan dengan benar dalam pemilihan jenis, dosis, volume semprot, cara aplikasi, interval maupun waktu aplikasinya. Terbatasnya tenaga kerja di kelompok tani bangkit Merbabu masih sering mengabaikan pengamatan hama penyakit yang ada. Untuk meningkatkan produktifitas brokoli organik dalam mengaplikasikan pestisida nabati perlu memperhatikan beberapa hal dianataranya adalah jenis pestisida nabati yang sesuai dengan hama penyakit, dosis yang digunakan, cara pengapikasikan pestisida dan interval maupun waktu aplikasinya.

Nilai koefisien regresi variabel mulsa $\left(X_{4}\right)$ sebesar $-1,186$ yang artinya jika penambahan mulsa satu satuan maka pendapatan usahatani mengalami penurunan sebesar 1,186 unit dengan asumsi pengunaan pengunaan biaya benih pupuk, pestisida nabati, wraping dan tenaga kerja tetap. Berdasarkan rekomendasi kelompok tani Bangkit Merbabu daya tahan mulsa bisa dugunakan sampai 3 musim tanam. Hasil 
penelitian di kelompok tani Bangkit merbabu daya tahan mulsa tidak semuanya bisa bertahan selama 3 musim tanam, ada sebagian yang harus diganti dengan mulsa baru sehingga mengakibatkan biaya produksi meningkat.Untuk meningkatkan produksi dan menambah pendapatan petani perlu adanya perlakuan secara hati hati saat proses tanam sampai dengan panen sehingga tingkat kerusakan mulsa bisa ditekan dan biaya produksi berkurang.

Nilai koefisien regresi variabel wrapping $\left(X_{5}\right)$ sebesar 5,716 yang artinya jika penambahan wrapping satu satuan maka pendapatan usahatani mengalami kenaikan sebesar 5,716 unit dengan asumsi pengunaan pengunaan biaya benih, pupuk, pestisida nabati, mulsa, dan tenaga kerja tetap. Wrapping atau plastik wrapping digunakan sebagai kemasan utama pada produk brokoli organik. Tujuan dari kemasan tersebut adalah untuk memperpanjang umur simpan brokoli organik. Menurut Sudarminto (2015) pengemasan dalam bungkus plastik dapat timbul udara termodifikasi yang menguntungkan, udara yang telah mengalami perubahan itu dapat memperpanjang umur simpan. Untuk meningkatkan harga brokoli organik bisa dilakukan dengan memperbaiki kemasan dengan ide-ide yang kreatif dan inovatif supaya konsumen banyak yang tertarik sehingga meningkatkan pendapatan petani.

Nilai koefisien regresi variabel tenaga kerja $\left(X_{6}\right)$ sebesar 8,726 yang artinya jika penambahan biaya tenaga kerja satu satuan biaya maka pendapatan usahatani mengalami kenaikan sebesar 8,726 unit dengan asumsi pengunaan biaya benih, pupuk, pestisida nabati, mulsa, wrapping tetap. Besarnya tenaga kerja pada usahatani brokoli organik sangat berpotensi dan faktor penentu keberhasilan dalam usahatani, mulai dari penyiapan lahan, pemeliharaan tanaman sampai pemanenen, mengingat budidaya organik membutuhkan penanganan tenaga kerja yang lebih intensif di dalam pengendalian hama dan penyakit karena mengunakan pengendalian mekanik, dibanding dengan pertanian konvensional. Secara statistik, penambahan biaya tenaga kerja dapat meningkatkan pendapatan, namun penambahan tenaga kerja bisa dilakukan dengan mengefektifkan tenaga kerja yang sudah ada dengan selektif dalam mengkaryakan tenaga kerja. Sehingga pengunanan tenaga kerja yang sama akan mencapai hasil maksimal, dan meningkatkan produksi yang dapat menaikan pendapatan usahatani.

Analisis koefisien determinasi Pada tabel 11 menunjukan nilai koefisien determinasi $=0,981 \mathrm{Hal}$ ini menunjukan kontribusi variabel independen $\mathrm{X}$ (benih, pupuk, pestisidanabati, mulsa, wrapping dan tenaga kerja ) yang sebenarnya adalah sangat kuat yaitu $98,1 \%$, sisanya $1,9 \%$ dipengaruhi variabel lain diluar penelitian seperti cuaca tanah dan air.

\section{KESIMPULAN DAN SARAN}

\section{A. Kesimpulan}

Berdasarkan dari hasil penelitian dan analisis data yang telah dilakukan, maka usahatani brokoli organik di kelompok tani Bangkit Merbabu desa Batur kecamatan Getasan kabupaten Semarang dapat disimpulkan sebagai berikut:

1. Usahatani brokoli organik kelompok tani Bangkit Merbabu desa Batur kecamatan Getasan 
kabupaten Semarang menguntungkan.

2. Usahatani brokoli organik kelompok tani Bangkit Merbabu desa Batur kecamatan Getasan kabupaten Semarang ini layak untuk diusahakan.

3. Sarana produksi dan tenaga kerja berpengaruh secara signifikan terhadap pendapatan.

\section{B. Saran}

1 Pengunaan benih terlalu banyak sehingga jarak tanam diperlebar agar tanaman dapat tumbuh dengan maksimal, yang akan meningkatkan hasil produksi dan pendapatan usahatani.

2 Pengunaan pupuk perlu diperhatikan terutama perbandingan antara pupuk padat dan pupuk cair. Perlu pengurangan dosis pupuk padat dan penambahan dosis pupuk cair dimana hal tersebut akan lebih menghemat alokasi biaya penggunaan pupuk. Selain itu pupuk cair juga lebih mudah diserap tanaman dibanding dengan pupuk padat.

3 Untuk mengurangi tingkat kerusakan penggunaan mulsa perlunya perlakuan secara hati hati saat proses budidaya brokoli organik mulai dari tanam sampai dengan panen sehingga biaya produksi berkurang dan pendapatan ushatani meningkat.

4 Inovasi penggunaan plastik wrapping dimana selain berfungsi sebagai kemasan atau untuk memperpanjan umur simpan juga bisa dijadikan alat untuk menarik konsumen sehingga pendapatan usahatani meningkat. Tenaga kerja dalam usahatani brokoli organik perlu ditambah atau mengefektifkan tenaga kerja yang sudah ada mengingat budidaya organik membutuhkan tenaga kerja yang intensif didalam perawatan terutama dalam pengendalian hama yang mengandalkan pengendalian secara mekanik atau manual.

\section{DAFTAR PUSTAKA}

Arikunto, 1998. Prosedur Penelitian Suatu Praktek. Melton Putra: Jakarta.

Balitsa, 2015. Manfaat Sayuran Organik. http://balitsa.litbang.pertanian.go. id/ ind /index.php/beritaterbaru/430-manfaat - sayuran organik. html diakses tangg al 9 November 2017

Daniel, M. 2002. Pengantar ekonomi pertanian. Bumi Aksara, Jakarta.

Gujarati, 1997. Ekonometrika Dasar. Alih Bahasa Sumarmo Zein. Erlangga. Jakarta

Herbarium Medanense. (2012). Identifikasi Tumbuhan. Herbarium Medanense Sumatera Utara, Medan.

Hernanto, F. 1995. IImu usahatani. Penebar Swadaya, Jakarta.

Kadariah, 1987. Pengantar Evaluasi Proyek. Lembaga Penelitian FakultasEkonomi Universitas Indonesia, Jakarta.

Kardinan, Agus.2014. Prinsip-Prinsip dan teknologi Pertanian Organik. IAARD press. Jakarta. 
Masyhuri, 2008. Metode Penelitian (Pendekatan Praktis dan Aplikatif). Refika Aditama, Bandung.

Mubyarto. 1994. Pengantar ekonomi pertanian. LP3ES, Jakarta.

Muhamad Syukur dan Maya Melati. 2016. Pengembangan Sayuran Organik. Departemen Agronomi dan Hortikultura, Fakultas Pertanian IPB.

Pracaya dan Juang G.K.2016. Bertanam 8 sayuran organik.Penebar Swadaya, Jakarta.

Prasetya, Hery dan Fitri Lukiastuti., 2009 - Manajemen Operasi. Media Pressindo, Yogyakarta.

Rubatzky, V. E., dan M. Yamaguchi. 1998. Sayuran Dunia. Prinsip, Produksi dan Gizi, Jilid 2. Penerbit ITB. Bandung.

Rukmana, 1994. Budidaya Kubis Bunga dan Brokoli. Kanisius, Yogyakarta.

Sidemen, I.G, Hartoyo dan Budikahono, G. 2012. Penguatan Kelembagaan Lokal dalam Pengembangan Pertanian Organik di Kecamatan Metro Kibang Kabupaten Lampung Timur. Seminar Hasil-Hasil Penelitian dan Pengabdian Kepada Masyarakat. Dies Natalis FISIP Unila Tahun 2012.
Soekartawi, 1995, Analisis Usahatani, UI Press, Jakarta.

Sudarminto. 2015. Peluang Usahatani Brokoli. Pustaka Baru Press, Yogyakarta.

Susilawati.2012. Analisis Keberlanjutan Usahatani Sayuran Organik Dalam Aspek Ekonomi. Program Studi Agribisnis, Fakultas Pertanian dan Bisnis UKSW Salatiga.

Sutanto, Rachman. 2002. Penerapan Pertanian Organik; $\mathrm{P}$ e mas y a r a k t a n dan Pengembangannya. Kanisius, Yogyakarta.

Wahyu. "Benih Unggul Brocoly Green Magic" https://bibit-unggulon line.blogspot.co.id /2016/11/benih-unggul-brocolygreen-magic.html/ diakses tanggal 16 Januari 2017. 